\title{
A selective medium for isolating Campylobacter jejuni/coli
}

\author{
FJ BOLTON, L ROBERTSON
}

From the Public Health Laboratory, Royal Infirmary, Meadow Street, Preston PR1 6PS

SUMMARY Skirrow's medium is effective for isolating Campylobacters from human faeces but is less suitable for animal and environmental specimens owing to the presence of contaminating species.

After determining the sensitivity of 104 strains of Campylobacters to several antimicrobial agents, used singly and in various combinations, a selective medium incorporating polymixin, rifampicin, trimethoprim and actidione, was developed. The medium, called Preston medium, was shown to be more selective than Skirrow's medium and suitable for any kind of specimen.

The first method for the isolation of Campylobacters from human faeces was differential filtration of a saline extract through a $0.65 \mu \mathrm{m}$ filter, which allows Campylobacters and other small bacteria to pass through. ${ }^{2}$ Thereafter the introduction of selective agars $^{34}$ proved successful for isolation from human faeces and so established Campylobacters as an important cause of enteritis in man. On occasions, however, both of these media can be overgrown by other organisms present in faeces and more frequently by organisms from other contaminated sources-for example, drain swabs, effluent from abattoirs, animal and avian faeces.

Campylobacters and other bacteria from human and animal sources were tested for sensitivity to a selection of antimicrobial agents; four of these were subsequently incorporated into a selective agar.

This paper assesses the use of the selective medium and compares it with Skirrow's medium for the isolation of Campylobacter jejuni/coli from human, animal, avian and environmental specimens.

\section{Material and methods}

ORGANISMS

One hundred and four strains of Campylobacter were investigated.

They included:

(a) Fifty strains isolated from human faeces, 10 from cattle rectal swabs, 23 from pig caecal swabs, 10 from chicken cloacal swabs, 10 from seagull faeces and one reference strain of Campylobacter jejuni (NCTC 11385).

(b) Thirty-nine other organisms which were isolated

Accepted for publication 13 July 1981 from clinical specimens or which had grown well on Skirrow's medium were also tested. They included 7 strains of Proteus spp, 5 of Escherichia coli, 6 of Klebsiella spp, 4 of Pseudomonas spp, 5 strains of faecal streptococci, 3 of Staphylococcus aureus, 2 of Staph albus, 4 of Bacillus spp and 3 of Lactobacillus spp.

\section{DETERMINATION OF MINIMUM INHIBITORY CONCENTRATION (MIC)}

The strains were preserved in $20 \%$ glycerol brain heart infusion broth and stored at $-70^{\circ} \mathrm{C}$. When required, the suspensions were thawed and inoculated onto Oxoid Columbia blood agar and incubated for $48 \mathrm{~h}$.

Colonies from the plates were harvested in phosphate-buffered saline (PBS). Standardised suspensions containing approximately $10^{8}$ organisms $/ \mathrm{ml}$ were prepared by adjusting the optical density visually to that of a standard Campylobacter suspension of known total viable count. The Campylobacters were then diluted in PBS to give approximately $10^{4}$ organisms $/ \mathrm{ml}$, and the other organisms to approximately $10^{6}$ organisms $/ \mathrm{ml}$.

A Denley multipoint inoculator was used to apply the organisms to the surface of a series of plates containing twofold dilutions of the antimicrobial agents. The medium used was Nutrient broth No 2 (Oxoid CM67) in $1.2 \%$ New Zealand agar, supplemented with $5 \%$ saponin-lysed horse blood. Controls included an agar plate without antibiotics and two organisms: the Oxford staphylococcus (NCTC 6571) and E coli (NCTC 10418).

The reproducibility of the results was established by retesting representative strains after a period of four weeks. The MIC was taken as the lowest 
concentration which gave complete inhibition of growth.

\section{ANTIMICROBIAL AGENTS}

The antimicrobial agents tested were polymixin $B$, vancomycin, trimethoprim lactate, rifampicin and actidione. All were supplied as powders of known potency and the first three were soluble in distilled water; rifampicin was dissolved initially in methanol, or dimethyl formamide; and actidione was dissolved initially in acetone. Stock solutions in distilled water were stored at $-20^{\circ} \mathrm{C}$ until required for incorporation into agar plates.

\section{QUANTITATIVE STUDIES}

The reference strain (NCTC 11385) and the four most sensitive Campylobacters found in the MIC studies were tested against varying concentrations of the four most suitable antimicrobial agents by the method of Miles and Misra. ${ }^{5}$

Suspensions of the five Campylobacters were prepared as for the MIC tests and tenfold dilutions from $10^{-1}$ to $10^{-8}$ were prepared in $0.1 \%$ peptone water. Dried plates were inoculated with five separate drops from a 50-dropper pipette and were incubated for $48 \mathrm{~h}$.

The concentrations of antibiotics incorporated into agar plates were: polymyxin $2 \cdot 5,5,10 \mathrm{IU} / \mathrm{ml}$, rifampicin $2 \cdot 5,5,10 \mu \mathrm{g} / \mathrm{ml}$, trimethoprim 10 , $80 \mu \mathrm{g} / \mathrm{ml}$, actidione $100 \mu \mathrm{g} / \mathrm{ml}$.

From the results of these test the most useful concentration of each antibiotic was incorporated in the following combinations: rifampicin and trimethoprim, rifampicin and polymyxin; polymyxin and trimethoprim; rifampicin, trimethoprim and polymyxin; rifampicin, trimethoprim, polymyxin and actidione. Skirrow's medium was also included for comparison. Counts were performed on three separate occasions; medium without antibiotics was included as a control.

\section{CAMPYLOBACTER ISOLATIONS}

\section{Media}

Two selective agars were used, Skirrow's medium ${ }^{3}$ and Preston medium. The latter was formulated from the results of the antibiotic experiments and had the following composition: Nutrient broth No 2 (Oxoid CM67) in $1.2 \%$ New Zealand agar, supplemented with $5 \%$ saponin-lysed horse blood and containing final concentrations of $5 \mathrm{IU} / \mathrm{ml}$ polymyxin, $10 \mu \mathrm{g} / \mathrm{ml}$ rifampcin, $10 \mu \mathrm{g} / \mathrm{ml}$ trimethoprim and $100 \mu \mathrm{g} / \mathrm{ml}$ actidione. The enrichment broth was the Preston medium without agar, distributed in $10 \mathrm{ml}$ amounts in $6^{\prime \prime} \times \frac{5}{8}$ " tubes. Inoculated broths were incubated for $24 \mathrm{~h}$ and then subcultured on Skirrow's medium and Preston medium.

Throughout the investigation all plates were incubated for $48 \mathrm{~h}$ at $43^{\circ} \mathrm{C}$ in an atmosphere containing approximately $6 \%$ (vol/vol) oxygen, $10 \%$ (vol/vol) carbon dioxide, and $84 \%$ (vol $/ \mathrm{vol}$ ) hydrogen.

\section{Specimens}

Thirty-five human faeces from which Campylobacters had been previously isolated on Skirrow's medium or on a prototype of the Preston medium were re-examined by direct culture and by enrichment. These specimens had been kept at room temperature for $48 \mathrm{~h}$ and therefore the numbers of Campylobacters in the faeces had declined but this was considered a more severe challenge to the two media. To determine the number of Campylobacters per gram of faeces at the time of testing a $10 \%$ suspension was made in physiological saline. Tenfold dilutions were prepared in saline up to $10^{-6}$. Surface viable counts ${ }^{5}$ were performed on the Preston agar.

To test the definitive Preston agar and enrichment broth, 200 cattle rectal swabs, 130 pig caecal swabs, 150 sheep rectal swabs, 50 chicken and 100 seagull cloacal swabs were cultured.

\section{Results}

Table 1 shows the minimum inhibitory concentrations (MIC) of the antibiotics for the 104 Campylobacter strains which were all resistant to $10 \mathrm{IU} / \mathrm{ml}$ polymyxin, $10 \mu \mathrm{g} / \mathrm{ml}$ rifampicin, and $80 \mu \mathrm{g} / \mathrm{ml}$ vancomycin. These Campylobacters were also resistant to $160 \mu \mathrm{g} / \mathrm{ml}$ trimethoprim and $800 \mu \mathrm{g} / \mathrm{ml}$ actidione.

Table 1 MIC distribution for 104 strains of Campylobacter jejuni/coli

\begin{tabular}{llllll}
\hline Antibiotic & \multicolumn{4}{l}{$\begin{array}{l}\text { Concentration of antibiotics in IU/ml } \\
\text { (polymyxin) }\end{array}$} & or $\mu \mathrm{g} / \mathrm{ml}$ (others) of agar \\
\cline { 2 - 6 } & $<10$ & 20 & 40 & 80 & $>80$ \\
\hline Polymyxin & 0 & 3 & 13 & 46 & 42 \\
Rifampicin & 0 & 2 & 7 & 19 & 76 \\
Vancomycin & 0 & 0 & 0 & 0 & 104 \\
\hline
\end{tabular}

Table 2 shows the distribution of the MIC's both for Gram-negative and Gram-positive organisms which had previously grown on Skirrow's medium and some of which had caused problems with the isolation of Campylobacters.

Polymyxin was active against Gram-negative bacteria only and $9 / 22$ gave MICs of $₹ 5 \mathrm{IU} / \mathrm{ml}$. The seven organisms with MICs $>80 \mathrm{IU} / \mathrm{ml}$ of 
Table 2 Distribution of MICs for 22 Gram-negative bacteria and 17 Gram-positive bacteria

\begin{tabular}{|c|c|c|c|c|c|c|c|c|}
\hline \multirow[t]{2}{*}{ Antibiotics and organisms } & \multicolumn{8}{|c|}{ Concentration of antibiotics in IU/ml (polymyxin) or $\mu g / m l$ (others) of agar } \\
\hline & $<2 \cdot 5$ & $2 \cdot 5$ & 5 & 10 & 20 & 40 & 80 & $>80$ \\
\hline \multicolumn{9}{|l|}{ Polymyxin } \\
\hline Gram-negative & 2 & 0 & 7 & 1 & 4 & 1 & $\mathbf{0}$ & 7 \\
\hline $\begin{array}{l}\text { Gram-positive } \\
\text { Rifampicin }\end{array}$ & $\mathbf{0}$ & $\mathbf{0}$ & $\mathbf{0}$ & 0 & 0 & 0 & 0 & 17 \\
\hline Gram-negative & 3 & 0 & 3 & 6 & 10 & 0 & 0 & 0 \\
\hline Gram-positive & 15 & 0 & 0 & 0 & 1 & 1 & 0 & 0 \\
\hline \multicolumn{9}{|l|}{ Vancomycin } \\
\hline Gram-negative & 0 & $\mathbf{0}$ & 0 & 0 & 0 & 0 & $\mathbf{0}$ & 22 \\
\hline Gram-positive & 5 & 0 & 1 & 2 & 1 & 3 & 0 & 5 \\
\hline Trimethoprim & $<5$ & 5 & 10 & 20 & 40 & 80 & 160 & $>160$ \\
\hline Gram-negative & 18 & 0 & 1 & $\mathbf{0}$ & 1 & 0 & 0 & 2 \\
\hline Gram-positive & 6 & 0 & 1 & 0 & $\mathbf{0}$ & 0 & $\mathbf{0}$ & 10 \\
\hline
\end{tabular}

polymyxin were Proteus spp which were inhibited by the concentration of trimethoprim in the final selective agar. The remaining six organisms with MICs $>5 \mathrm{IU} / \mathrm{ml}$ were Pseudomonas spp and Klebsiella spp.

Rifampicin showed activity against Gram-negative and Gram-positive bacteria. Twelve of 22 Gramnegative bacteria had MICs $<10 \mu \mathrm{g} / \mathrm{ml}$ while $15 / 17$ Gram-positive bacteria had MICs $<2.5 \mu \mathrm{g} / \mathrm{ml}$. The two most resistant organisms were streptococci.

Vancomycin was inactive against the Gramnegative bacteria and the range of sensitivities to both Gram-positive and -negative bacteria confirm why most had previously grown on Skirrow's medium which contains $10 \mu \mathrm{g} / \mathrm{ml}$ vancomycin. Vancomycin is less selective than rifampicin and it was not considered necessary to include it in the final medium.

With trimethoprim 19/22 Gram-negative bacteria were susceptible to $10 \mu \mathrm{g} / \mathrm{ml}$ and Pseudomonas spp were the three most resistant strains. The Grampositive organisms were more resistant in that 10 organisms gave MICs $>160 \mu \mathrm{g} / \mathrm{ml} ; 7 / 10$ of these organisms were faecal streptococci or lactobacilli and Waterworth ${ }^{6}$ states that this apparent resistance occurs because unlike other organisms Streptococcus faecalis can utilise thymine. However, the majority of these Gram-positive bacteria would be inhibited by the concentration of rifampicin selected for the final medium.

These results indicate that $10 \mathrm{IU} / \mathrm{ml}$ polymyxin, $10 \mu \mathrm{g} / \mathrm{ml}$ rifampicin, $10 \mu \mathrm{g} / \mathrm{ml}$ trimethoprim and $100 \mu \mathrm{g} / \mathrm{ml}$ actidione would be reasonable concentrations of antibiotics to be incorporated into a selective medium. Vanhoof et al $^{7}$ found that the 6/95 Campylobacters had MICs of polymyxin at $10 \mathrm{IU} / \mathrm{ml}$ and our own pilot study of three selective agars containing various concentrations of antibiotics indicated that $5 \mathrm{IU} / \mathrm{ml}$ of polymyxin was the more suitable concentration.

Table 3 shows the quantitative counts of the most sensitive Campylobacters on media containing combinations of antibiotics. The sources of these Campylobacters were: pig; cow; human; seagull; and NCTC 11385 reference strain. The results indicate that there was some variation between counts on the different antibiotic media, but these differences were not statistically significant. The two selective agars gave slightly lower counts than the control medium but this was to be expected as most inhibitory media have this effect. However the Preston medium gave significantly higher counts than Skirrow's medium with three of the five strains tested $(p=0.05)$.

\section{CAMPYLOBACTER ISOLATION}

Table 4 shows that the Preston medium was more succesful than Skirrow's medium for the isolation of Campylobacter from human faeces. From these known positive faeces the Preston medium isolated Campylobacter from $31 / 35$ specimens while Skirrow's medium isolated $17 / 35$. The four specimens which were negative on the Preston medium had Campylobacter counts of less than $5 \times 10^{3}$ organisms $/ \mathrm{g}$.

Table 5 shows these four counts were amongst the lowest obtained from any of the 35 faeces. In comparison the results of Skirrow's medium showed a failure to isolate Campylobacter from specimens with a wide range of counts. The two specimens negative on Skirrow's medium, but with counts $>10^{6}$ organisms $/ g$, were overgrown, one with Pseudomonas spp and the other with Klebsiella spp. The qualitative results from Table 4 also indicate that Campylobacters produced more growth on the Preston medium from the majority of specimens. Table 7 shows the results of the animal and avian specimens which confirmed that the Preston medium was superior for the isolation of Campylobacter from cattle, pigs and seagulls but similar to Skirrow's medium for isolation from sheep and chickens.

The results of the human faeces shows that the Preston medium is more selective than Skirrow's 
Table 3 Mean quantitative counts (Miles and Misra) of the five selected Campylobacters tested on agar containing combinations of antibiotics

\begin{tabular}{|c|c|c|c|c|c|}
\hline \multirow[t]{2}{*}{ Antibiotic combinations and concentrations } & \multicolumn{5}{|c|}{ Bacterial counts of five Campylobacters $\times 10^{9}$ organisms $/ \mathrm{ml}$ from five sources } \\
\hline & Pig & Cow & Human & Seagull & $\begin{array}{l}\text { NCTC } \\
\text { reference strain }\end{array}$ \\
\hline $\begin{array}{l}\text { Rifampicin } 10 \mu \mathrm{g} / \mathrm{ml} \\
\text { Trimethoprim } 10 \mu \mathrm{g} / \mathrm{ml}\end{array}$ & $5 \cdot 3$ & $6 \cdot 5$ & 6.9 & $3 \cdot 3$ & $4 \cdot 6$ \\
\hline $\begin{array}{l}\text { Rifampicin } 10 \mu \mathrm{g} / \mathrm{ml} \\
\text { Polymyxin } 5 \mathrm{IU} / \mathrm{ml}\end{array}$ & $5 \cdot 0$ & $5 \cdot 3$ & $7 \cdot 9$ & 3.9 & $4 \cdot 7$ \\
\hline $\begin{array}{l}\text { Trimethoprim } 10 \mu \mathrm{g} / \mathrm{ml} \\
\text { Polymyxin } 5 \mathrm{IU} / \mathrm{ml}\end{array}$ & $9 \cdot 3$ & $7 \cdot 2$ & $6 \cdot 3$ & $3 \cdot 0$ & $5 \cdot 9$ \\
\hline $\begin{array}{l}\text { Rifampicin } 10 \mu \mathrm{g} / \mathrm{ml} \\
\text { Trimethoprim } 10 \mu \mathrm{g} / \mathrm{ml} \\
\text { Polymyxin } 5 \mathrm{IU} / \mathrm{ml}\end{array}$ & $5 \cdot 2$ & $6 \cdot 3$ & $5 \cdot 5$ & $3 \cdot 3$ & $5 \cdot 3$ \\
\hline $\begin{array}{l}\text { Rifampicin } 10 \mu \mathrm{g} / \mathrm{ml} \\
\text { Trimethoprim } 10 \mu \mathrm{g} / \mathrm{ml} \\
\text { Polymyxin } 5 \mathrm{IU} / \mathrm{ml} \\
\text { Actidione } 100 \mu \mathrm{g} / \mathrm{ml}\end{array}$ & $4 \cdot 0$ & $5 \cdot 3$ & $5 \cdot 3$ & $2 \cdot 7$ & $4 \cdot 5$ \\
\hline Skirrow's medium & $2 \cdot 0$ & $3 \cdot 7$ & $1 \cdot 7$ & $2 \cdot 5$ & $5 \cdot 9$ \\
\hline Control medium without antibiotics & $7 \cdot 2$ & $7 \cdot 8$ & $6 \cdot 5$ & $4 \cdot 5$ & $6 \cdot 0$ \\
\hline
\end{tabular}

Table 4 Comparison of the two media for the isolation of Campylobacters from 35 known positive faeces

\begin{tabular}{|c|c|c|c|c|c|c|c|c|}
\hline \multirow[t]{2}{*}{ Media } & \multicolumn{4}{|c|}{ Growth of Campylobacters } & \multicolumn{4}{|c|}{ Growth of other organisms } \\
\hline & +++ & ++ & + & 0 & +++ & ++ & + & 0 \\
\hline \multicolumn{9}{|l|}{ Direct plating: } \\
\hline Skirrow's medium & 8 & 5 & 4 & 18 & 15 & 12 & 2 & 6 \\
\hline Preston medium & 18 & 10 & 3 & 4 & 2 & 4 & 7 & 22 \\
\hline \multicolumn{9}{|l|}{ Enrichment: } \\
\hline Skirrow's medium & 28 & 4 & 1 & 2 & 2 & 2 & 8 & 23 \\
\hline Preston medium & 30 & 3 & 2 & $\mathbf{0}$ & 0 & 1 & 0 & 34 \\
\hline
\end{tabular}

Table 5 Quantitative counts of Campylobacters in the 35 known positive faeces

\begin{tabular}{llll}
\hline Counts (organisms/g) & $\begin{array}{l}\text { No of faeces within } \\
\text { each range }\end{array}$ & $\begin{array}{l}\text { No of specimens } \\
\text { Campylobacter-negative } \\
\text { within each range }\end{array}$ \\
\cline { 2 - 4 } & & $\begin{array}{l}\text { Skirrow's } \\
\text { medium }\end{array}$ & $\begin{array}{l}\text { Preston } \\
\text { medium }\end{array}$ \\
\hline$<10^{3}$ & 4 & 3 & 2 \\
$10^{3}-10^{4}$ & 8 & 6 & 2 \\
$10^{4}-10^{5}$ & 10 & 6 & 0 \\
$10^{5}-10^{6}$ & 7 & 1 & 0 \\
$>10^{6}$ & 6 & 2 & 0 \\
\hline
\end{tabular}

medium (Tables 4 and 6). In fact, organisms other than Campylobacters were found from $82 \%$ of cultures on Skirrow's medium in comparison to $40 \%$ of cultures on Preston medium. Qualitatively $170 / 300$ human faeces (Table 6) gave a moderate $(++)$ or greater growth on Skirrow's medium in comparison to only 33/300 on Preston medium.

The animal and avian results (Table 8 ) confirmed the improved selectively of the Preston medium in that $395 / 630$ specimens showed growth of other
Table 6 Comparison of the two media for the isolation of Campylobacters and the inhibition of normal flora from 300 human faeces

\begin{tabular}{lcc}
\hline Growth & Skirrow's medium & Preston medium \\
\hline Campylobacters pure & 6 & 7 \\
$\quad$ growth & & \\
Camplylobacters plus & 1 & 0 \\
$\quad$ other organisms & & \\
Other organisms & 64 & 7 \\
+++ & 105 & 26 \\
++ & 69 & 45 \\
+ & 6 & 22 \\
\pm & 49 & 193 \\
0 & & \\
\hline
\end{tabular}

All culture plates were examined and the results recorded qualitatively as follows:

+++ Growth over the whole of the inoculated area.

+ Growth over two-thirds of the inoculated area.

$+>10$ colonies on the primary inoculum.

$\pm \quad<10$ colonies on the primary inoculum.

No bacterial growth.

organisms on Skirrow's medium in comparison to 67/630 specimens inoculated onto the Preston medium. The organisms most frequently encountered 
Table 7 Comparison of culture methods for isolation of Campylobacters for animal and avian specimens

\begin{tabular}{lrclc}
\hline Specimen No & $\begin{array}{l}\text { Total isolated } \\
\text { on Skirrow's } \\
\text { medium }\end{array}$ & $\begin{array}{l}\text { Total isolated } \\
\text { on Preston } \\
\text { medium }\end{array}$ & $\begin{array}{l}\text { Total isolated } \\
\text { by enrichment }\end{array}$ \\
\hline Cattle & 200 & 1 & 11 & 47 \\
Pig & 130 & 23 & 97 & 121 \\
Sheep & 150 & 6 & 7 & 40 \\
Chicken & 50 & 47 & 50 & 50 \\
Seagull & 100 & 8 & 18 & 35 \\
\hline
\end{tabular}

Table 8 Direct culture plates showing presence of other organisms from animal and avian specimens.

\begin{tabular}{lrll}
\hline Specimen & No & Skirrow's medium & Preston medium \\
\hline Cattle & 200 & 172 & 28 \\
Pig & 130 & 108 & 19 \\
Sheep & 150 & 16 & 0 \\
Chicken & 50 & 25 & 0 \\
Seagull & 100 & 74 & 20 \\
\hline
\end{tabular}

on Skirrow's medium varied with the type of specimen; human specimens yielded pseudomonads, coliforms, streptococci, and from 14/300 specimens Proteus spp were isolated, whilst the non-human specimens yielded psuedomonads, coliforms, fungi, spreading Bacillus spp from cattle specimens and Proteus spp from chicken and seagull specimens.

Table 4 shows that the enrichment method isolated Campylobacter from $35 / 35$ known positive specimens including the four specimens which were negative by direct plating on Preston medium. The subculture plates of both media showed much fewer contaminants and an improved growth of Campylobacter than on Skirrow's medium. The animal and avian specimens (Table 7) show that enrichment gave more positive Campylobacter isolations than direct plating. Campylobacters were isolated on Skirrow's medium from $85 / 630$ specimens, on Preston medium from 183/630 specimens, and by enrichment from $293 / 630$ specimens.

\section{Discussion}

Skirrow's medium has proved successful for the isolation of Campylobacters from human faeces but we encountered a number of "contaminant" organisms in specimens from other sources which indicated the need for a more selective medium. Bacillus spp frequently isolated from cattle rectal swabs produced a spreading growth over the surface of the medium and their colonial morphology was very similar to that of Campylobacters, the only obvious difference between them being their odour. These Bacillus spp were an even greater problem in specimens taken during the winter when the animals were fed on hay. Proteus spp were a problem during the isolation of Campylobacters from poultry faeces for, like the Bacillus spp, they swarmed on the surface of Skirrow's medium. From drain swabs and effluents the problem organisms were pseudomonads, coliform bacilli and fungi which produced overgrowth on Skirrow's medium which decreased Campylobacter isolation.

Skirrow's medium which uses blood agar base No 2 (Oxoid) contains trimethoprim at a final concentration of $5 \mu \mathrm{g} / \mathrm{ml}$ which should therefore inhibit all but the most resistant strains of Proteus spp. However, during some laboratory MIC tests with trimethoprim incorporated into various basal media a discrepancy was observed between MIC results on DST agar (Oxoid) and on blood agar base No 2 .

As blood agar base No 2 contains yeast extract, saponin-lysed blood is added to neutralise the trimethoprim antagonists but when the MIC results for 20 organisms, which included Staphylococcus, Streptococcus, E coli, Klebsiella and Proteus, were compared against those obtained from DST agar they were at least ten times higher. We concluded that blood agar No 2 even with $5 \%$ saponin-lysed horse blood added must still contain trimethoprim antagonists. Nutrient broth No 2 (Oxoid) in $1.2 \%$ New Zealand agar does not contain yeast extract and gave comparable MIC results to DST agar and this was chosen as a more suitable base for a selective medium because the trimethoprim was still active. In this study all MIC tests were performed on Nutrient broth No 2 in $1.2 \%$ New Zealand agar and on DST agar as a control.

The Bacillus spp grew in the presence of $10 \mu \mathrm{g} / \mathrm{ml}$ of vancomycin and either this antibiotic should be replaced or the concentration increased. Bacitracin is used in Butzler's medium as an alternative to vancomycin, but a final concentration greater than $100 \mathrm{IU} / \mathrm{ml}$ is required to inhibit Bacillus spp; this was considered too expensive.

From these studies and the in-use comparisons it is evident that the Preston medium is more selective than Skirrow's medium and is more successful for the isolation of Campylobacters from environmental, animal, poultry and human sources. It has eliminated many of the contaminating organisms which can mask the presence of Campylobacter but it is not totally selective because some pseudomonads, coliforms and faecal streptococci show growth which is usually restricted to the area of the primary inoculum.

Although the new agar medium gave increased isolation of Campylobacters the enrichment method was even more successful. Enrichment may not be necessary for the laboratory diagnosis of acute infections in man, when greater numbers of Campylo- 
bacters are present in stools but it may be useful for the accurate determination of asymptomatic Campylobacter carriers and for studies involving the survival of small numbers of Campylobacters. The importance of enrichment was confirmed during an investigation of a milk borne outbreak, ${ }^{8}$ when 9/80 cow rectal swabs were Camplylobacterpositive by enrichment culture only. Skirrow's medium was used at this time for direct plating and many cow rectal cultures were overgrown with swarming Bacillus spp.

The agar medium and the enrichment broth have been used successfully for the past two and a half years for the isolation of Campylobacters from coastal sea water samples, from drain swab effluent and environmental specimens from local abattoirs.

\section{References}

${ }^{1}$ Dekeyser P, Gossuin-Detrain M, Butzler JP, Sternon J. Acute enteritis due to related vibrio: first positive stool cultures. J Infect Dis 1972;125:390-2.

${ }^{2}$ Butzler JP, Dekeyser P, Detrain M, Dehaen F. Related vibrio in stools. J Pediatr $1973 ; 82: 493-5$.

${ }^{3}$ Skirrow MB. Campylobacter enteritis: a "new" disease. Br Med J 1977;ii:9-11.

' Lauwers S, De Boeck M, Butzler JP. Campylobacter enteritis in Brussels. Lancet 1978; $: 604$.

${ }^{5}$ Miles AA, Misra SS. The estimation of the bactericidal power of the blood. J Hyg 1938;38:732.

${ }^{6}$ Waterworth P, Reeves DS, Philips I, Williams JP, Wise R. Laboratory methods in antimicrobial chemotherapy. Edinburgh: Churchill Livingstone, 1978:82-4.

${ }^{7}$ Vanhoof R, Vanderlinden MP, Dierickx R, Lauwers S, Yourassowsky E, Butzier JP. Susceptibility of campylobacter fetus to twenty nine antimicrobial agents. Antimicrob Agents Chemother 1978;14,4:553-6.

${ }^{8}$ Robinson DA, Edgar WM, Gibson GL, Matchett AA, Robinson $\mathrm{L}$. Campylobacter enteritis associated with the consumption of unpasteurised milk. $\mathrm{Br}$ Med J 1979;i:1171-3.

Requests for reprints to: Mr FJ Bolton, Public Health Laboratory, Royal Infirmary, Meadow Street, Preston PR1 6PS, England. 